\title{
Growth of Service Sector in India
}

\author{
Latha C. M., Dr. V. Shanmugam \\ ${ }^{*}$ Research Scholar DOS in Economics and Co-Operation University of Mysore \\ ${ }^{* 2}$ Assistance Professor, Maharaja Evening College, University of Mysore
}

\begin{abstract}
Health and education service sector in India our wide range of service provides an end-to-end solution to all our needs in the education sector. Health is defined as a state of complete physical, mental and social well being and just not the non existence of disease or aliment. The expansion of both health and education sector have made the advancement of service sector. Fisher and Colin Clark have divided the economy into primary sector, secondary sector and tertiary sector. Service sector activities include trade, commerce, transport, communication, hotel and restaurant, banking and finance, health and education, tourism, share market, film industry, insurance, astrology industry etc. India service sector accounts more than 50 per cent of India's Gross Domestic Product (G.D.P). There is a significant changes in sectoral contribution of each sector to india's GDP over a period of time. Share of other services and service sector in percent and the performance of growth rates of service sector and GDP. In the decades of year 1950-51 to 2010-11
\end{abstract}

\section{Introduction}

As civilization progresses human desires increase leading to the evolution of economic activities. Normally primary activities such as hunting, animal husbandry and agriculture emerged. Later on as science and technological development tookplace which led to the evolution of industrial sector. The expansion of both these sectors made the advancement of service sector.

Fisher (1935) and Colin Clark (1940) have divided the economy into primary sector, secondary sector and tertiary sector. The primary sector which covers tangible goods in agriculture, forestry, fishing, and hunting. The secondary sector includes mining, manufacturing and such activities as gas, electricity and water supply involving activities with a tangible and product. The tertiary sector consists of trade and public services. But this is not a clear cut division on economic activities as economist change the activity in the list and also there is overlapping of economic activities.

Later on the economic activities have been shifted from one sector to other sector. At present the primary sector includes agriculture, forestry, animal and husbandry and fisheries etc., the secondary sector activities incorporate mining, manufacturing, electricity, gas, water supply, construction etc., the service sector activities include trade, commerce, transport, communications, hotel and restaurant, banking and finance, health and education, tourism, share market, film industry, insurance, astrology industry, advertisement industry, sports, legal service, publishing industry, mass media etc.,

Service sector also known as the tertiary sector of the economy is expanding at a faster rate. It is one of the three sectors of the economy. "Soft" part of the economy in the service sector includes all activities which people offer their knowledge and time to improve productivity, performance, potential and sustainability and also known as advice, experience and discussion include the service sector. Service sector involves of activities beginning from the production of goods and service until it reaches to the consumer. For the last 30 years there has been a substantial shift from the primary and secondary sector to the service sector. Now it has become a largest sector of the economy. Further, the service sector activities can be grouped into:

1. Trade, hotel and restaurants.

2. Transport, storage and communication. Transport includes roads and railways, airways and inland and overseas, water transport.

3. Financial institutions, insurance, real estate and business services.

4. Community, social and personal services. Community services include government establishment and it's departments and personal services such as health, and education, NGOs etc.

Eventhough there is a thin margin in distinguishing between private sector and public services, because some services are being provided by both the sectors. We can classify the service sector activities coming under the both sectors. Private services include trade, commerce, transport, communication, hotel and restaurant, tourism, insurance, cinema, advertisement, sports, health and education, level service and NGOs etc. Government sector includes government establishment including legislature, executive, judiciary, its various departments at central and state government and its autonomous bodies and local bodies. 


\subsection{Objectives:-}

1. To analyze the service sector growth in India

2. To analyze the implemented of Health services

3. To analyze the implemented of education services.

\subsection{Methodology:-}

The study is based on secondary sources obtained from economic survey Government of India. Information about specific parameters outlined in the objectives was collected for the period between 1950-51 and 2010-11. The detailed information was collected from economic survey 2011-12 and a data sheet was proposed. Performance of Health and Education has been used to analyze the performance of Health and Education.

\subsection{Role of Service Sector in Economic Development:}

In any country economic development depends on the growth and evolution of the three sectors of the economy. However in recent years the service sector growing at a very faster rate in the developing countries and is contributing a major share in terms of output, income and employment. Even the productivity per worker is becoming higher in service sector when compared to agriculture and industrial sectors. Already the service sector is dominant in the developed countries. If agriculture sector is stagnant, new service activities are emerging and adding to the service sector making the economy to grow. Hence service sector is playing a major role in economic development of any country.

The importance of the services sector can be gauged by its contributions to different aspects of the economy.

Business include both domestic trade as well as foreign trade. Trade as a service sector activities facilitates the exchange of the goods and services between producers and consumers. Domestic trade refers to the exchange of goods and services with in the country. Which provides income and employment to the people who have engaged in this activities. Foreign trade plays a major role in the development of the country. Imports of machinery and equipment which cannot be produced in the initial stages at home are essential. Such imports which either help to create new capacity in some lines of production or enlarge capacity in the other lines of production are called developmental imports. The imports which are made in order to make a full use of the productive capacity are called maintenance imports.

Finance as a service sector activity plays an important role in undertaking any economic activities. Finance refers to funds of monetary resources required by individual, business houses and the government. People needs funds to meeting their current requirement or day to day of expenses for buying capital goods. A business house require funds for paying wages and salaries, for buying raw materials, for purchasing new machinery or replacing an old one etc. Government needs funds to provide various services to its subject. Finance institutions provides funds to various groups of people for variety of activities. In this process the service sector activities provides income and employment to the people of a country.

In the previous days this sector is responsible for distributing the output of the primary and secondary sectors for the intermediate and final consumption and also for the providing a variety of services to producers as well as consumers. Trade, transport and storage activities ensure distribution of goods and services where and when needed by consumers. Business and financial services facilitate mobilization of resources and their development in the activities of different sector of the economy.

Service sector activities generally require relatively less capital investment than activities in other sectors. But a majority of these activities also require relatively less space for operations service sector is a knowledge intensive sector and substantial HRD inputs are the necessary for developing most of the services sector activities.

\subsection{Service Sector in India:}

Today, in India service sector accounts more than 50 percent of India's Gross Domestic Product (GDP). There is a significant changes in sectoral contribution of each sector to India's GDP over a period of time. In 1950-51 the primary sector was contributing about 56.5 percent to the Indian GDP. It is followed by the secondary sector with 13.6 percent and tertiary sector with 29.9 percent. During 1990-91 the share of agriculture sector in India GDP was 34 percent. It was followed by secondary sector with 23.2 percent and tertiary sector with 42.8 percent. During 2007 the contribution of primary sector came down to 18 percent, and industrial sector increased to 29 percent sector to 53 percent (Misra and Puri, 2009). During 2008-09 the share of primary sector was 15.7 percent, the share of secondary sector was 28 percent and the share of service sector was 56.4 percent (GOI, 2010) which highlights the fact that the share of tertiary sector is raising constantly over a period of time. 
The segment of the economy that provides services to its consumers is the tertiary sector. This includes wide range of businesses and also including financial institutions, schools, transports and restaurants. And also known of the tertiary sector or service industry / sector.

India stands one of the leading economy because its growth has been led by the Service sector. It's a larger part of the Indian economy both in terms of employment potential and its contribution to national income.

Demand and supply factors have led to this growth. In the demand side high growth of services is the economy was mostly due to the factors such as the increasing input usage of services by other sectors. In the supply side is the increased trade in services following trade in liberalization policies and other reforms of 1990s induced this growth.

The trade liberalization is responsible for the development of finance, transport communication and other service sector activity including in service hotel and restaurant. Along with this the increase in demand for health and education also led to expansion of these sector.

The services sector in future providing about the 70 per cent of the new job opportunities in the economy as the share agriculture in total employment already falling, in the coming years, the share of services would increase.

The Indian economy has contributed to the services sector of about 55.2 per cent share in G.D.P its growing by 10 per cent annually, contributing to the total employment, a high share in foreign direct investment and one-third of total exports and recording very fast at 27.4 per cent in export growth of the first half of 201011. While latest available data has been taken from the national and international sources.

Some services, such as infrastructure include the roads, railways, civil aviation, financial services and social services. The social services including the health and education play a major role in enhancing the contribution of service sector to its Indian economy.

In India the contribution of service sector to the Indian G.D.P ( Gross Domestic Product) is classified in three heads. In the first head Trade, Hotles, Transport and Communication. In the second head Financing, Insurance, Real estate and Business services. In third head Other services along with Public Administration and defense and Health and Education sectors have been incorporated.

\subsection{Health Service Sector in India:}

Health is defined as a state of complete physical, mental and social well being and just not the non existence of disease or ailment. The health service sector is a primary human right and has been accorded due to an importance by constitution through Article 21. In the Article 21 stresses upon the state government to safeguard the health and nutritional well being of the people, the central government also plays an active role in the sector.

The Indian Health sector consists of:

1. Medical care providers like physicians, specialist clinics, nursing homes, hospitals.

2. Diagnostic service centers and pathology laboratories

3. Medical equipment manufactures

4. Contract research organization (C.R.Os) pharmaceutical manufactures etc.,

\subsection{Education service sector in India:}

Our wide range of services provides an end -to-end solution to all our needs in the education sector. The education sector in India is poised at a crucial stage in its growth. India's demographic advantage of having a large population of youth, coupled with low gross enrolment ratios, presents a huge opportunity to education sector players.

At the same time, the growth of the Indian economy and upward movement of income levels is boosting spend on education. Which already accounts for the second-highest share wallet for the middle-class households.

Government support for the education sector has also seen a boost, with substantial reforms and increased financial outlays being announced and implemented.

\subsection{Performance of the Service sector in India:}

The growth of service sector in India has been evaluated in terms of the percentage share to the G.D.P. The following sections deal with these issues in detail. 


\section{Share of service sector in GDP (in per cent) At Constant 2004-2005 Prices Rs Crore}

\begin{tabular}{|l|l|l|l|}
\hline \multicolumn{1}{|c|}{ Year } & Service Sector & G.D.P & Per cent $(\%)$ \\
\hline $1950-1951$ & 82591 & 279618 & 29.5 \\
\hline $1960--1961$ & 123872 & 410279 & 39.1 \\
\hline $1970-1971$ & 196158 & 589787 & 33.2 \\
\hline $1980-1981$ & 300613 & 798506 & 37.6 \\
\hline $1990-1991$ & 573465 & 1347889 & 42.5 \\
\hline $2000-2001$ & 1179976 & 2342774 & 50.3 \\
\hline $2010-2011$ & 2818125 & 4885954 & 57.6 \\
\hline
\end{tabular}

Source: GOI, 2012 Economic Survey .

During 1950-51 the contribution of service sector to G.D.P was 29.5 per cent. In 1960-61 it was 39.1 per cent its increasing the per cent. In 1970-71 it was 33.2 per cent this period decreasing the per cent. In 198081 it was 37.6 per cent. In 1990-91 contribution of service sector to G.D.P was 42.5 per cent this period share of per cent increasing. 2000-2001 this period also increase the 50.3 per cent. During 2010-11 the share of service sector to G.D.P was 57.6 per cent over a period of time between 1950-2011 the contribution service sector has doubled.

\subsection{Share of Other Services and G.D.P (in per cent)}

\begin{tabular}{|l|l|l|l|}
\hline Year & Other Service & G.D.P & Per cent (\%) \\
\hline $1950-1951$ & 28474 & 279618 & 10.1 \\
\hline $1960--1961$ & 40741 & 410279 & 9.9 \\
\hline $1970-1971$ & 68218 & 589787 & 11.5 \\
\hline $1980-1981$ & 101666 & 798506 & 12.7 \\
\hline $1990-1991$ & 180564 & 1347889 & 13.3 \\
\hline $2000-2001$ & 343963 & 2342774 & 14.6 \\
\hline $2010-2011$ & 637675 & 4885954 & 13 \\
\hline
\end{tabular}

Source: GOI, 2012 Economic Survey .

During 1950-51 the contribution of other services and G.D.P was 10.1 per cent . In 1960-61 it was 9.9 per cent this period decreasing the per cent. In 1970-71 it was share of per cent 11.5 per cent. In 1980-81 it was 12.7 per cent. In 1990-91 it was 13.3 per cent, 2000-01 it was 14.6 per cent. 2010-11 the share of other service to G.D.P was 13 per cent . Over a period of time between 1950-2011 the contribution of other services is little bit increasing.

\subsection{Share of Other Services and Service Sector (in per cent)}

\begin{tabular}{|l|l|l|l|}
\hline Year & Other Service & Service Sector & Per cent (\%) \\
\hline $1950-1951$ & 28474 & 82591 & 34.4 \\
\hline $1960--1961$ & 40741 & 123872 & 32.8 \\
\hline $1970-1971$ & 68218 & 196158 & 34.7 \\
\hline $1980-1981$ & 101666 & 300613 & 33.8 \\
\hline $1990-1991$ & 180564 & 573465 & 31.4 \\
\hline $2000-2001$ & 343963 & 1179976 & 29.1 \\
\hline $2010-2011$ & 637675 & 2818125 & 22.8 \\
\hline
\end{tabular}

Source: GOI, 2012 Economic Survey .

During 1950-51 the contribution of other services and service sector was 34.4 per cent . In 1960-61 it was 32.8 per cent. In 1970-71 it was share of per cent 34.7. In 1980-81 it was 33.8 per cent. In 1990-91 it was 31.4 per cent, 2000-01 it was 29.1 per cent. During 2010-11 the share of other service to service sector was 22.8 per cent . Over a period of time between 1950-2011 the contribution of other services to service sector has been decreasing.

\subsection{Performance of Growth Rates of Service Sector and G.D.P:}

In the coming section an attempt has been made to discuss the growth rate of service sector and G.D.P. The simple growth rate has been calculate for each decade. 
1.3 Percentage Growth Rate of Service Sector and G.D.P in India:

\begin{tabular}{|l|l|l|l|l|}
\hline Year & Service Sector & Per cent & G.D.P & Per cent \\
\hline $1950-1951$ & 82591 & - & 279618 & - \\
\hline $1960--1961$ & 123872 & 49.9 & 410279 & 46.7 \\
\hline $1970-1971$ & 196158 & 58.3 & 589787 & 43.7 \\
\hline $1980-1981$ & 300613 & 53.2 & 798506 & 35.3 \\
\hline $1990-1991$ & 573465 & 90.7 & 1347889 & 68.8 \\
\hline $2000-2001$ & 1179976 & 105.7 & 2342774 & 73.8 \\
\hline $2010-2011$ & 2818125 & 138.8 & 4885954 & 108.5 \\
\hline
\end{tabular}

Source: GOI, 2012 Economic Survey.

The above table reveals some trends. It is clear that the growth rates have been fluctuated in the study period for all the service sector and G.D.P

In the first decades of development between 1950-51 and 1960-61 the growth rate of G.D.P was 46.7 per cent and service sector growth rate was 49.9 per cent. In the second decades of during 1960-61 and 1970- 71 the growth rate of G.D.P was 43.7 per cent and service sector growth rate was 58.3 per cent. In the third decades between 1970-71 and 1980-81 the growth rate of G.D.P was 35.3 and service sector growth rate was 53.2 per cent. In the forth decades between 1980-81 and 1990-91 the growth rate of G.D.P was 68.8 per cent and service sector growth rate was 90.7 per cent. In the fifth decades 1990-91 and 2000-2001 the growth rate of G.D.P was 73.8 per cent and service sector growth rate was 105.7 per cent. In the last decades during 2000-2001 and 20102011 the growth rate of G.D.P was 108.5 per cent and service sector growth rate was 138.5 per cent in the same period.

1.4 Percentage Growth Rate of Other Services and G.D.P in India:

\begin{tabular}{|l|l|l|l|l|}
\hline Year & Other Service & Per cent & G.D.P & Per cent \\
\hline $1950-1951$ & 28474 & - & 279618 & - \\
\hline $1960--1961$ & 40741 & 43 & 410279 & 46.7 \\
\hline $1970-1971$ & 68218 & 67.4 & 589787 & 43.7 \\
\hline $1980-1981$ & 101666 & 49 & 798506 & 35.3 \\
\hline $1990-1991$ & 180564 & 77.6 & 1347889 & 68.8 \\
\hline $2000-2001$ & 343963 & 90.4 & 2342774 & 73.8 \\
\hline $2010-2011$ & 637675 & 85.3 & 4885954 & 108.5 \\
\hline
\end{tabular}

Source: GOI, 2012 Economic Survey.

The above table reveals some trends. It is clear that the growth rates have been fluctuated in the study period for all the other services and G.D.P

In the first decades of development between 1950-51and 1960-61 the growth rate of G.D.P was 46.7 per cent and other services growth rate was 43 per cent. In the second decades of during 1960-61 and 1970- 71 the growth rate of G.D.P was 43.7 per cent and other services growth rate was 67.4 per cent. In the third decades between 1970-71 and 1980-81 the growth rate of G.D.P was 35.3 and other services growth rate was 49 per cent. In the forth decades between 1980-81 and 1990-91 the growth rate of G.D.P was 68.8 per cent and other services growth rate was 77.6 per cent. In the fifth decades 1990-91 and 2000-2001 the growth rate of G.D.P was 73.8 per cent and other services growth rate was 90.4 per cent. In the last decades during 2000-2001 and 2010-2011 the growth rate of G.D.P was 108.5 per cent and other services growth rate was 85.3 per cent in the same period.

\section{Conclusion}

As civilization progresses human desires increase leading to the evolution of education activities. The expansion of both health and education sectors have made the advancement of service sector. The service sector can be ganged by its contribution to different aspect of the economy. In the decade period between 2000-01 and 2010-11. Was highly increased in compare1950-51 to 2000-01. This period service sector and other services have been increased.

[2]. Economic Survey 2011-12

[3]. Economic Agricultural Statistics at a Glance 2010, Directorate of Economics and Statistics, Ministry of Agricultural, Government of India.

[4]. Fisher G.B. Alan "The Clash of Progress and Security “, Macmillan, London, 1935.

[5]. Government of Karnataka (2006), Karnataka Human Development Report 2005, Planning and Statistics, Government of Karnataka, Bangalore, p.15.

[6]. Misra and Puri (2009), "Indian Economy", $27^{\text {th }}$ revised Edition, Himalaya Publishing House, Pvt. Ltd., Ramdoot , Dr. Bhalerao Marg, Girgan, Mumbai-400004, pp59 to 64

[7]. Ruddar Datt and Sundharam (2007), "Indian Economy", 55 ${ }^{\text {th }}$ revised Edition, Chand and Company Ltd.,Ramnagar, New Delhi-110055, pp 742,830 .

[8]. Suryanaryanan S. S (1996), “The Service Sector And Its Role In Economic Development”, The Indian Journal of Labour Economics, vol.. 39(1), 1996, pp.65.

[9]. www.service sector

[10]. www.service sector in India 